\title{
KEGIATAN PENGEMBANGAN KEAKSARAAN BERBASIS PENDIDIKAN KARAKTER DI TAMAN KANAK-KANAK
}

\author{
Barokah Widuroyekti1) \\ Dwi Sambada2) \\ Tri Dyah Prastiti3) \\ 1) Program Studi PGPAUD, FKIP Universitas Terbuka \\ UPBJJ-UT Surabaya, Kampus C Unair Jl. Mulyorejo Surabaya \\ 2) Program Studi Pendidikan IPS, FKIP Universitas Terbuka \\ UPBJJ-UT Surabaya, Kampus C Unair JI. Mulyorejo Surabaya \\ 3) Program Studi Pendidikan Matematika, FKIP Universitas Terbuka \\ UPBJJ-UT Jember \\ e-mail: barokahw@ecampus.ut.ac.id
}

\begin{abstract}
The study was aimed to develop character-education-based literacy activities through the children active involvement ofliteracy practice in kindergarten. In particular, the aim is (1) the analysis of the needs and constraints to obtain baseline data; (2) designing and developing a guidebook for character-based literacy activities with the active involvement of children in the literacy practice in kindergarten. The study was carried out by using a development research approach. The research subjects consisted of 22 kindergarten teachers and childrens from three kindergarten institutions. The research location is three kindergartens in Jombang, namely: TK Pembina Gudo, TK Negeri Pembina Jombang, and TK AI Wardah Peterongan. Data were collected through observation, interviews, scrutiny of documents, materials selection, and material mapping. Data were analyzed with descriptive techniques. Test the validity of product development validation performed by two groups of product development validator, the validator group practitioners/teachers (V1) and validator expert (V2). The results showed that the literacy hear-speak on a kindergartner who stand out include the ability to: retell stories read, perform songs, and participate in the conversation. As the literacy skills to read and write show the emergence of capabilities: holding the book from the right side, turning the page on the right side; show interest in writing; and draw/scribble and can tell by the picture. The result of the development is the Activity Books for Literacy Development Character-Education-Based, as a handbook for teachers. An assessment of the validity of product developmentcarried out on four aspects, namely the aspects of substance, presentation, linguistic, and graphic design. Validity test results showed that the quality of the product development of products in general have met the quality of "good" and "excellent". Recommendations for kindergarten teachers to conduct literacy activities by including elements of character education in all of the planning component of literacy learning, includes the objective component, material and activities procedure.
\end{abstract}

Keywords: activities, character education, literacy 


\begin{abstract}
ABSTRAK
Penelitian ini bertujuan untuk mengembangkan kegiatan keaksaraan berbasis karakter melalui pelibatan aktif praktik keaksaraan anak TK. Secara khusus tujuannya adalah (1) analisis kebutuhan dan kendala untuk memperoleh data dasar; (2) mendesain dan mengembangkan buku panduan kegiatan keaksaraan berbasis karakter dengan pelibatan aktifanak dalam praktik keaksaraan di TK. Penelitian dilakukan dengan menggunakan pendekatan penelitian pengembangan. Subyek penelitian terdiri atas 22 orang guru TK dan anak-anak TK yang berasal dari tiga lembaga TK. Lokasi penelitian adalah tiga TK di Kabupaten Jomban, yakni TK Pembina Kecamatan Gudo, TK Negeri Pembina Kecamatan Jombang, dan TK Al Wardah Kecamatan Peterongan. Data dikumpulkan melalui observasi, wawancara, pencermatan dokumen, seleksi bahan, dan pemetaan materi. Data dianalisis dengan teknik deskriptif. Uji validitas produk pengembangan dilakukan validasi produk pengembangan oleh dua kelompok validator, yakni kelompok validator praktisi/guru (V1) dan validator ahli (V2). Hasil penelitian menunjukkan bahwa literasi dengar-bicara pada anak TK yang menonjol meliputi kemampuan: menceritakan kembali cerita yang dibacakan, melakukan nyanyian, dan ikut serta dalam percakapan. Adapun kemampuan literasi bacatulis menunjukkan kemunculan kemampuan: memegang buku dari sisi kanan, membalik halaman dari sisi kanan; menunjukkan ketertarikan terhadap tulisan; dan membuat gambar/coretan dan dapat bercerita dengan gambar tersebut. Hasil pengembangan adalah Buku Kegiatan untuk Pengembangan Keaksaraan Berbasis Pendidikan Karakter, sebagai buku panduan untuk guru. Penilaian terhadap validitas produk pengembangan dilakukan terhadap empat aspek, yakni aspek substansi, penyajian, kebahasaan, dan kegrafikan. Hasil uji validitas produk menunjukkan bahwa kualitas produk pengembangan secara umum telah memenuhi kualitas "baik" dan "sangat baik". Rekomendasi bagi guru TK adalah melaksanakan kegiatan keaksaraan dengan cara memasukkan unsur-unsur pendidikan karakter pada semua komponen perencanaan pembelajaran keaksaraan, meliputi komponen tujuan, materi, dan prosedur kegiatan.
\end{abstract}

Kata kunci: keaksaraan, kegiatan, pendidikan karakter

Pengembangan kemampuan keaksaraan sudah dimulai sejak anak berada di Taman Kanakkanak melalui kegiatan menstimulasi kemunculan perkembangan dengar-bicara-baca-tulis. Keaksaraan (literasi) bagi anak TK adalah kegiatan pengembangan kemampuan dengar-bicarabaca-tulis sebagai proses belajar sepanjang hidup yang dilandasi kemampuan mendengarkan dan berbicara, dan setahap demi setahap menuju kemampuan keaksaraan/baca-tulis. Literasi merupakan kemampuan penting sebagaimana dinyatakan Strickland (1998) bahwa Literacy melibatkan kemampuan memecahkan masalah, berpikir kritis dan kreatif, dan komunikasi efektif. Para pakar bahasa merekomendasikan kegiatan program baca-tulis yang mendorong emergent literacy (Strickland, 1990; Teale \& Sulzby, 1986 dalam Cooper 2000). Emergent mengandung makna bahwa kesadaran perkembangan baca-tulis timbul dari anak, yang terjadi secara bertahap dari waktu ke waktu dan beberapa kemampuan dasar pemahaman kata telah dimiliki anak. Literacy (kemampuan dengar-bicara-baca-tulis) akan muncul ketika kondisi baik (Hall, 1986 dalam Burns, 1996). Dalam konteks ini, aktivitas keaksaraan dilakukan dengan pelibatan aktif siswa TK dalam praktik membaca dan menulis pada semua aspek perkembangan melalui berbagai kegiatan yang menyenangkan dan 
pilihan bahan bacaan literature/cerita/big book, kerajinan, menggambar, serta media pendukung sesuai karakter dan usia anak.

Literasi pada konteks anak TK memiliki pengertian yang berbeda dengan pengertian umum, yakni mengacu kepada pengertian literasi awal atau kemunculan literasi (emergentliteracy). Istilah kemunculan literasi digunakan sebagai pengganti dari istilah kesiapan membaca (reading readiness). Marrie Clay (dalam Spodek \& Saracho, 1994) menggunakan istilah emergent literacy untuk merujuk kepada istilah early literacy (literasi awal). Kemunculan literasi merupakan tahap awal perkembangan kearah literasi, yang mengawali tahap membaca tulisan dalam pengertian konvensional. Kemunculan literasi pada anak dapat diketahui ketika anak mulai mencorat-coret di kertas atau papan meskipun tidak tampak adanya tulisan huruf. Kemunculan literasi juga dapat diketahui ketika anak memberikan kesan terhadap membaca atau mengisahkan tentang cerita saat mereka melihat tulisan dan gambar pada buku. Aktivitas tersebut dianggap sebagai perilaku keaksaraan yang sah (Morrow, 1993, dalam Spodek \& Saracho, 1994).Perkembangan literasi dimulai sejak awal kehidupan anak dan berlangsung terus setiap hari dalam kehidupan di rumah dan di masyarakat.

Selain munculnya literasi, usia dini merupakan usia kritis bagi pembentukan karakter seseorang. Sebagaimana dikemukakan AI-Qairawani (dalam Megawangi, 2009) bahwa sifat-sifat buruk yang timbul dari anak bukanlah fitrah melainkan karena kurangnya peringatan sejak dini dari orang tua dan pendidik. Semakin dewasa usia anak maka semakin sulit pula baginya untuk meninggalkan sifat-sifat buruk. Orang tua yang selalu memperingatkan dan mencegah anaknya dari sifat-sifat buruk sejak dini telah menyiapkan dasar kuat bagi kehidupan anak di masa datang. Pernyataan tersebut menyiratkan pentingnya pendidikan karakter dimulai sejak usia dini. Pendidikan karakter dapat dilakukan melalui cerita yang dibacakan oleh orang tua/guru atau melalui kegiatan membaca buku bersama anak. Melalui kegiatan mendengarkan cerita dan membaca buku bersama, anak dapat belajar keterampilan membaca menulis sekaligus mengidentifikasi berbagai karakter tokoh yang ada dalam cerita. Masa kanak-kanak disebut juga dengan masa meniru, misalnya meniru pembicaraan atau tindakan orang di sekitarnya, baik pembicaraan atau tingkah laku yang baik atau pun yang buruk.

Pengembangan literasi sejak usia TK menjadi hal yang krusial dan mendesak untuk dilaksanakan mengingat anak adalah sumber daya manusia (SDM) untuk menyiapkan generasi emas tahun 2045. Pembentukan SDM harus dimulai sejak usia dini, sejak anak memasuki dunia pendidikan formal di TK. Sumber daya manusia yang dibutuhkan untuk terciptanya generasi emas adalah sumber daya yang memiliki keterampilan dalam kehidupan dan karir, keterampilan dalam belajar yang mencakup $4 \mathrm{C}$, yakni critical thingking, communication, collaboration, creativity, dan keterampilan menguasai teknologi, informasi, dan media. Selain memiliki pengetahuan yang luas, juga harus ditunjang dengan kemampuan kreatif, berpikir kritis, dan berkarakter (Kemdikbud, 2015). Disini lah pentingnya pengembangan kemampuan literasi, yang menyiapkan anak dalam menghadapi tantangan di era digital dan informasi tanpa mengesampingkan pendidikan karakter.

Pembelajaran di TK sebagai bentuk pengembangan berbagai kompotensi anak dilakukan secara terpadu sesuai dengan karakteristik anak yang memandang dunia secara holistik. Pendidikan karakter merupakan salah satu aspek pengembangan yang dilakukan secara terintegrasi dengan pengembangan kompetensi yang lain. Pendidikan karakter dapat dimulai sejak usia dini melalui pendidikan di TK sebagaimana dikemukakan oleh Montessori (dalam Megawangi, 2009) bahwa otak adalah "absorbent mind", yaitu ibarat sponge kering, apabila dicelupkan ke dalam air maka akan menyerap air dengan cepat. Apabila yang diserap adalah air bagus maka baguslah ia. Sebaliknya, apabila yang diserap adalah hal-hal yang tidak baik maka jeleklah ia. Dengan demikian, pendidikan 
karakter yang dimulai sejak usia dini akan memberikan dasar dan stimulasi yang baik bagi tumbuhnya karakter baik bagi anak.

Pentingnya pendidikan karakter sejak usia dini telah banyak diungkapkan oleh tokoh. Sebagaimana diungkapkan oleh Froebel, bahwa anak kodratnya bersifat baik. Sifat buruk anak sebenarnya timbul karena kurangnya pendidikan. Masa anak merupakan fase yang sangat fundamental bagi perkembangan individu karena pada fase inilah terjadinya peluang yang cukup besar untuk pembentukan dan pengembangan pribadi seseorang. Apabila anak mendapatkan pengasuhan yang tepat, maka seperti halnya tanaman muda akan berkembang secara wajar mengikuti hukumnya sendiri (dalam Candrawaty, 2015).

Karakter dan pribadi yang baik bukanlah sesuatu yang terpisah dan berdiri sendiri melainkan berhubungan erat dengan pengetahuan dan keterampilan yang dimiliki oleh individu. Oleh karena itu, pendidikan karakter tidak bisa dipisahkan dari pendidikan secara keseluruhan. Wardani (2009) mengemukakan bahwa pendidikan karakter merupakan pendidikan yang terintegrasi dalam semua kegiatan pendidikan termasuk dalam bidang studi. Dikatakan bahwa karakter tidak dapat dipisahkan dari konteks sosial budaya karena karakter atau kepribadian seseorang terbentuk dalam lingkungan sosial budaya tertentu. Dicontohkan pula sifat-sifat baik seperti toleran, jujur, simpati, empati, saling menghormati, kritis, kreatif, kooperatif, disiplin, tanggung jawab merupakan contoh-contoh sifat baik yang bersifat universal untuk dapat dikembangkan dalam konteks pendidikan karakter di Indonesia yang multi-kultural.

Dalam kurikulum TK, kurikulum pendidikan karakter juga tercakup dalam lingkup pengembangan nilai-nilai agama dan moral. Tingkat pencapaian perkembangan merupakan standar pencapaian minimal yang harus dilalui anak. Pada usia 5-6 tahun, tingkat pencapaian perkembangan nilai-nilai agama dan moral adalah: mengenal agama yang dianut; membiasakan diri beribadah; memahami perilaku mulia (jujur, penolong, sopan, hormat, dan sebagainya); membedakan perilaku baik dan buruk; mengenal ritual dan hari besar agama; dan menghormati agama orang lain (Kemdiknas, 2010).

Sementara itu, pengembangan bahasa termasuk di dalamnya pengembangan literasi literasi tidak bisa dilakukan secara terpisah-pisah melainkan dilakukan secara terpadu dan holistik. Melalui pengenalan tentang buku dan cerita anak dalam pembelajaran anak dikenalkan dengan nilai-nilai karakter yang baik. Melalui struktur cerita anak dapat mengidentifikasi tokoh dan bisa meniru perilaku tokoh. Sebagimana pernyataan Hurlock (2007) bahwa pendidikan karakter pada anak TK dapat dilakukan melalui cara identifikasi. Obyek identifikasi dapat berupa tokoh-tokoh cerita yang dikenalkan melalui buku literatur anak. Melalui tokoh cerita, anak dapat belajar dan meniru pola perilaku tokoh dalam kisah/cerita. Charlote Huck (dalam Ellis dkk, 1989) mengemukakan nilai-nilai literatur bagi kehidupan anak, yang diklasifikasikan dalam nilai-nilai instrinsik dan ekstrinsik. Kontribusi literatur terhadap kehidupan anak yang berupa nilai intrinsik meliputi: kesenangan, pengembangan pribadi, dan pemahaman terhadap orang lain dan dunia. Melalui buku, anak memperoleh kesenangan. Kesenangan dengan buku merupakan hal utama dari pengalaman berhubungan dengan bacaan/cerita. Kesenangan yang diperoleh dari buku akan memperkokoh komitmen pribadi untuk membaca dan komitmen tersebut akan berkembang sepanjang kehidupan mereka.

\section{METODE}

Penelitian ini menggunakan pendekatan penelitian Research and Development (R \& D) yakni penelitian yang akan menghasilkan produk dan menguji keefektifan produk (Sugiyono, 2009) atau 
penelitian yang ditindaklanjuti dengan pengembangan dan diseminasi (Borg \& Gall, 1983), dimodifikasi sesuai konteks yang ada. Penelitian diawali dengan analisis kebutuhan, kajian teori sebagai dasar pemetaan tema, tujuan, materi, dan kegiatan. Hasil pemetaan digunakan untuk mendesain draf kegiatan keaksaraan berbasis pendidikan karakter di TK. Selanjutnya draf di validasi oleh ahli isi yakni ahli dalam pendidikan PAUD, ahli bahasa, dan ahli dalam pembelajaran.

Survey lapangan dilakukan dengan menyebarkan angket untuk guru tentang kebutuhan pengembangan kegiatan keaksaraan berbasis pendidikan karakter di TK Jombang. Angket untuk guru berisi tentang kondisi pembelajaran kekaksaraan dan pendidikan karakter di TK yang selama ini dilakukan guru dan kendala serta kebutuhan guru dalam pembelajaran keaksaraan. Pengkajian teori juga dilakukan untuk memperoleh data tentang keaksaraan atau literasi, pendidikan TK, pendidikan karakter, bahan ajar, dan kurikulum TK 2013 yang berlaku di TK. Data lapangan ini kemudian dianalisis untuk diambil simpulan sementara tentang kebutuhan guru berkaitan dengan pembelajaran keaksaraan berbasis pendidikan karakter di TK.

Teknik observasi dilakukan untuk memperoleh data perkembangan literasi anak yang muncul ketika melakukan kegiatan pembelajaran di TK. Kegiatan observasi dilakukan dengan cara berkolaborasi bersama guru-guru TK. Untuk melengkapi data perkembangan literasi anak juga dilakukan diskusi dengan kelompok guru melalui forum Focus Group Discussion (FGD).

Subyek penelitian adalah para guru TK di Kabupaten Jombang dari 3 lembaga pendidikan TK, sebanyak 22 orang. Dalam proses pembelajaran juga terlibat anak-anak TK dari 3 lembaga TK di Kabupaten Jombang. Subjek penelitian dari anak-anak TK pada masing-masing TK hanya akan diambil dari kelompok B, yakni kelompok anak-anak usia 5-6 tahun, yang merupakan kelompok persiapan memasuki jenjang pendidikan sekolah dasar.

Data penelitian hasil kuesioner dianalisis secara persentase dan dijelaskan deskriptif. Data hasil uji validitas dianalisis dengan teknik analisis kualitatif.

\section{HASIL PENELITIAN}

Hasil penelitian tentang perkembangan anak TK, dapat dilihat perkembangan literasi anak, meliputi dengar-bicara, baca-tulis, serta perkembangan perilaku prososial. Perkembangan kemampuan dengar-bicara meliputi sembilan indikator, yakni: (1) mendengar tapi tidak bicara, (2) memberikan jawaban satu kata, (3) memberikan respon frasa singkat, (4) melakukan nyanyian, (5) ikut serta dalam percakapan, (6) berbicara dalam kalimat yang panjang, (7) mengajukan pertanyaan, (8) bisa mengisahkan cerita sendiri, dan (9) bisa menceritakan kembali cerita. Secara umum perkembangan anak menunjukkan kemunculan pada semua indicator.

Hasil penelitian tentang perkembangan kemampuan baca-tulis pada anak TK menunjukkan bahwa sebagian anak belum muncul beberapa indikator antara lain: menyalin kata-kata dari berbagai sumber/buku, menggabungkan huruf-huruf atau coretan yang menyerupai kata, menceritakan kembali kisah yang dibacakan, menulis nama sendiri atau inisial, dan menulis dari kiri ke kanan.

Data tentang perkembangan prososial terkait dengan pembentukan karakter baik menunjukkan kemunculan pada semua indicator, meliputi: menunjukkan kepedulian bagi seseorang yang kesusahan, berbagi sesuatu dengan anak lain, memberikan sesuatu kepada anak lain, mengambil giliran tanpa kerewelan, memenuhi permintaan tanpa kerewelan, membantu anak lain mengerjakan tugas, dan membantu/peduli pada orang lain yang membutuhkan.

Temuan penelitian berkaitan dengan kendala dan kebutuhan guru adalah sebagai berikut.

1) Sebagian besar guru memahami kegiatan pengembangan literasi atau keaksaraan sebagai kegiatan yang bekaitan dengan baca-tulis-hitung (calistung). 
2) Pendidikan karakter di TK dilakukan melalui pembiasaan yang dimasukkan dalam Standard Operational Procedure (SOP). SOP ini disusun untuk digunakan sebagai pedoman guru dalam melakukan pendidikan karakter melalui pembiasaan, meliputi: SOP Penyambutan, SOP Pembukaan, SOP Istirahat, dan SOP Penutup.

3) Pendidikan karakter yang dilakukan dalam kegiatan pengembangan keaksaraan dilakukan dengan pembisaan membaca buku secara bebas. Kegiatan ini dimaksudkan untuk memperluas wawasan dan literasi anak serta menumbuhkan minat baca bagi anak.

4) Kesulitan yang dihadapi guru dalam pengembangan keaksaraan di TK adalah penyesuaian dengan kurikulum baru yaitu dari Kurikulum PAUD 2013. Kesulitan yang dialami guru terutama dalam menyusun perencanaan program sesuai dengan tuntutan kurikulum 2013.

5) Kebutuhan yang dirasakan guru dalam pelaksanaan praktik keaksaraan di TK adalah kebutuhan menyangkut sumber belajar dan materi kegiatan.

6) Guru merasa perlu adanya pelatihan yang khusus untuk pengembangan keaksaraan karena selama ini belum pernah diadakan.

Berdasarkan temuan penelitian tentang perkembangan anak dan kendala serta kebutuhan guru, selanjutnya dikembangkan kegiatan pembelajaran keaksaraan berbasis pendidikan karakter di TK. Kegiatan pengembangan keaksaraan disusun dengan memperhatikan prinsip belajar sambil bermain. Oleh karena itu, kegiatan yang dikembangkan memasukkan unsur-unsur permainan dengan menggunakan alat main edukatif dan bahan-bahan yang beraneka macam dan menyenangkan. Kegiatan pengembangan keterampilan dengar-bicara dirancang melibatkan anak secara aktif dalam percakapan, baik antar guru-anak maupun antar anak-anak. Kegiatan-kegiatan tersebut dirancang melalui perencanaan yang sistematis dengan memerhatikan: tujuan, tema, subtema, muatan materi (meliputi keterampilan keaksaraan dan pendidikan karakter), dan jenis kegiatan. Demikian pula dalam pengembangan keaksaraan terkait baca-tulis dikembangkan kegiatan keaksaraan yang diarahkan untuk menstimulasi perkembangan anak berhubungan dengan buku, tertarik terhadap buku atau tulisan, dan kegiatan baca-tulis serta bercerita.

\section{Hasil Validasi}

Hasil pengembangan produk berupa Draf Buku Kegiatan Keaksaraan Berbasis Pendidikan Karakter di Taman Kanak-kanak. Produk pengembangan yang telah dihasilkan tersebutdivalidasi oleh dua kelompok validator. Validator 1 (V1) adalah kelompok praktisi pendidikan TK dan validator 2 (V2) adalah validator ahli. Kriteria penilaian dibagi dalam empat kategori, yakni: sangat baik (3,5-4), baik $(2,6-3,4)$, kurang baik $(1,6-2,5)$, sangat kurang baik $(0-1,5)$. Selain berupa hasil penilaian, validasi juga memberi rekomendasi dan masukan dari validator untuk perbaikan terhadap draf awal. Aspek yang dinilai meliputi substansi, penyajian, kebahasaan, dan kegrafikan. Hasil validasi menunjukkan nilai baik pada setiap butir pada semua aspek.

Ditinjau dari aspek substansi, data pada Tabel 1 menunjukkan bahwa hasil validasi dari kelompok validator 1 dan 2 memberikan nilai rata-rata baik pada kriteria: kesesuaian tujuan pengembangan dengan kompetensi dasar anak TK, keterpaduan kegiatan keaksaraan dengan pendidikan karakter, kesesuaian kegiatan dengan karakteristik anak TK, dan kesesuaian pendidikan karakter dengan konteks budaya anak. Adapun pada dua kriteria memperoleh nilai sangat baik, yaitu criteria kesesuaian materi dengan tingkat pencapaian perkembangan dan pelibatan aktif anak dalam kegiatan keaksaraan. 
Tabel 1. Hasil Validasi Aspek Substansi

\begin{tabular}{cllccc}
\hline I. & Substansi & \multicolumn{3}{c}{} \\
\cline { 3 - 4 } No & \multicolumn{1}{c}{ Kriteria } & \multicolumn{2}{c}{ Skor } & $\begin{array}{c}\text { Rata- } \\
\text { rata }\end{array}$ & Nilai \\
\cline { 2 - 4 } & Rt2 V1 & Rt2 V2 \\
\hline 1 & $\begin{array}{l}\text { Kesesuaian tujuan pengembangan dengan } \\
\text { kompetensi dasar anak TK }\end{array}$ & 3,125 & 3.5 & 3,3 & Baik \\
\hline 2 & $\begin{array}{l}\text { Keterpaduan kegiatan keaksaraan dan } \\
\text { pendidikan karakter }\end{array}$ & 3,25 & 3.5 & 3,4 & Baik \\
\hline 3 & $\begin{array}{l}\text { Kesesuaian materi dengan Tingkat } \\
\text { Pencapaian Perkembangan }\end{array}$ & 3,5 & 4 & 3,8 & Sangat baik \\
\hline 4 & $\begin{array}{l}\text { Kesesuaian kegiatan dengan karakteristik } \\
\text { anak TK }\end{array}$ & 2,625 & 4 & 3,3 & Baik \\
\hline 5 & $\begin{array}{l}\text { Pelibatan aktif anak dalam kegiatan } \\
\text { keaksaraan }\end{array}$ & 3,375 & 4 & 3,7 & Sangat baik \\
\hline 6 & $\begin{array}{l}\text { Kesesuaian pendidikan karakter dengan } \\
\text { konteks budaya anak }\end{array}$ & 3 & 2.5 & 2,8 & Baik \\
\hline
\end{tabular}

Hasil uji validasi produk pengembangan aspek penyajian sebagaimana pada Tabel 2.

Tabel 2. Hasil Uji Kualitas Produk Pengembangan Aspek Penyajian

\begin{tabular}{llclll}
\hline II. & Penyajian & \multicolumn{5}{c}{} \\
\hline No & \multicolumn{1}{c}{ Kriteria } & \multicolumn{2}{c}{ Skor } & $\begin{array}{l}\text { Rata- } \\
\text { rata }\end{array}$ & Nilai \\
\hline & & Rt2 V1 & Rt2 V2 \\
\hline 1 & Teknik penyajian & 3,25 & 3,5 & 3,4 & Baik \\
\hline 2 & Penyajian kegiatan pembelajaran & 3 & 3,5 & 3,3 & Baik \\
\hline 3 & Kelengkapan penyajian & 2,5 & 3 & 2,8 & Baik \\
\hline 4 & Kemudahan dalam penggunaan & 2,5 & 3,5 & 3,0 & Baik \\
\hline
\end{tabular}

Data pada Tabel 2 menunjukkan bahwa rata-rata hasil validasi dari kelompok validator 1 dan 2 pada aspek penyajian memperoleh nilai baik, meliputi teknik penyajian, penyajian kegiatan pembelajaran, kelengkapan, dan kemudahan dalam penggunaan.

Hasil validasi produk pengembangan pada aspek kebahasaan meliputi empat criteria, yakni criteria: keterbacaan, kekomunikatifan, keruntutaan kalimat, dan kepaduan gagasan. Hasil penilaian kelompok validator 1 dan 2 disajikan pada Tabel 3.

Data pada Tabel 3 menunjukkan bahwa hasil uji kualitas produk pengembangan pada aspek kebahasaan memperoleh nilai "baik" pada semua kriteria, yakni kriteria keterbacaan kekomunikatifan, keruntutan kalimat, dan kepaduan gagasan. Dengan demikian, secara umum kualitas produk pengembangan pada aspek kebahasaan telah memenuhi kualitas baik. 
Tabel 3. Hasil Uji Kualitas Produk Pengembangan Aspek Kebahasaan

\begin{tabular}{|c|c|c|c|c|c|}
\hline \multirow[b]{2}{*}{ No } & \multirow[b]{2}{*}{ Kriteria } & \multicolumn{2}{|c|}{ Skor } & \multirow[b]{2}{*}{$\begin{array}{c}\text { Rata- } \\
\text { rata }\end{array}$} & \multirow[b]{2}{*}{ Nilai } \\
\hline & & $\begin{array}{l}\text { Rt2 } \\
\text { V1 }\end{array}$ & Rt2 V2 & & \\
\hline 1 & Keterbacaan & 3,125 & 3,5 & 3,313 & Baik \\
\hline 2 & Komunikatif & 2,875 & 4 & 3,438 & Baik \\
\hline 3 & Keruntutan kalimat & 3,375 & 3,5 & 3,438 & Baik \\
\hline 4 & Kepaduan gagasan & 2,5 & 3,5 & 3 & Baik \\
\hline
\end{tabular}

Hasil validasi terhadap aspek kegrafikan meliputi tiga criteria, yakni criteria: ukuran buku, desain sampul buku, dan desain isi buku. Data hasil validasi disajikan pada Tabel 4.

Tabel 4. Hasil Uji Kualitas Produk Pengembangan Aspek Kegrafikan

\begin{tabular}{clllll}
\hline IV. & \multicolumn{3}{c}{ KegrafikanPenyajian } & \multicolumn{3}{c}{ Skor } & \multirow{2}{*}{$\begin{array}{l}\text { Rata- } \\
\text { Nata }\end{array}$} & \multirow{2}{*}{ Nilai } \\
\cline { 3 - 5 } No & \multirow{2}{*}{ Kriteria } & $\begin{array}{c}\text { Rt2 } \\
\text { V1 }\end{array}$ & $\begin{array}{c}\text { Rt2 } \\
\text { V2 }\end{array}$ & & \\
& & 3 & 3,5 & 3,3 & Baik \\
\hline 1 & Ukuran buku & 3,625 & 3 & 3,3 & Baik \\
\hline 2 & Desain sampul buku & 3 & 3 & 3,0 & Baik \\
\hline 3 & Desain isi buku & & &
\end{tabular}

Data pada Tabel 4 menunjukkan bahwa hasil uji validasi terhadap produk pengembangan pada aspek kegrafikan menunjukkan kualitas "baik" untuk seluruh kriteria, yaitu aspek ukuran buku, desain sampul buku, dan desain isi buku. Dengan demikian, secara umum dapat dinyatakan bahwa kualitas kegrafikan adalah baik sampai sangat baik.

\section{PEMBAHASAN}

Pengembangan kegiatan keaksaraan berbasis pendidikan karakter merupakan pengembangan model-model kegiatan di TK, yang dilakukan dengan memasukkan unsur-unsur pendidikan karakter secara terintegrasi dalam kegiatan pengembangan kompetensi di TK. Kompetensi yang akan dicapai meliputi 4 kompetensi inti yang dijabarkan ke dalam kompetensikompetensi dasar. Dalam penelitian ini, kompetensi dasar yang menjadi focus terutama kompetensi berhubungan dengan pengembangan bahasa dan karakter.

Pendidikan karakter di TK yang selama ini dilakukan oleh guru di TK adalah melalui kegiatan pembiasaan, yakni pembiasaan saat kedatangan, pembukaan, istirahat dan saat pulang. Kegiatan pembiasaan tersebut disusun dalam SOP, meliputi: SOP Penyambutan, SOP Pembukaan, SOP Istirahat, dan SOP Penutup. Pendidikan karakter melalui pembiasaan ini merupakan upaya sengaja untuk membentuk karakter dengan cara mengulang-ulang perilaku baik sehingga diinternalisasi oleh individu. Pengulangan tersebut dimaksudkan agar perilaku tersebut menjadi milik individu dan menjadi karakter atau membentuk kepribadian anak.

Pengembangan kegiatan di TK yang mengintegrasikan dengan pendidikan karakter merupakan upaya pembentukan karakter melalui melalui contoh baik dan pengajaran langsung. 
Dengan demikian nilai-nilai kebaikan itu ditangkap (melalui contoh yang baik) dan diajarkan (melalui penjelasan langsung) oleh guru (Lickona, 2013: 106). Melalui cerita tentang kejadian atau cerita tentang tokoh-tokoh baik, guru melanjutkan dengan penjelasan langsung tentang perilaku yang baik. Artinya, nilai-nilai kebaikan diberikan melalui contoh-contoh dalam berperilaku baik dan diajarkan melalui penjelasan dan penyadaran. Dengan demikian, akan terjadi pembentukan karakter melalui tiga aspek yang saling berkaitan, yakni: pengetahuan moral, perasaan moral, dan perilaku moral (Lickona, 2013: 72).

Pengembangan literasi melalui keterlibatan aktif anak dalam praktik keaksaraan di TK memungkinkan anak mengembangkan keaksaraan melalui kegiatan yang sengaja dirancang oleh guru dalam perencanaan pembelajaran. Dalam hal ini, sebelum kegiatan dilakukan, guru telah membuat perencanaan yang meliputi penetapan tujuan pengembangan, materi pembelajaran, serta langkah-langkah kegiatan yang akan dilakukan. Tujuan pengembangan disusun secara eksplisit meliputi kompetensi dasar yang akan dicapai secara integratif mencakup kompetensi bahasa serta kompetensi terkait pendidikan karakter.

Pemilihan sumber belajar serta buku bacaan anak juga harus menjadi perhatian guru. Pemilihan buku cerita/sastra anak yang baik untuk pengembangan keaksaraan sekaligus sebagai sarana pembentukan karakter perlu mempertimbangkan muatan pesan moral dalam cerita. Pesan moral dalam cerita yang merupakan konten pendidikan karakter menjadi penting untuk diintegrasikan dalam kegiatan keaksaraan yang melibatkan keaktifan anak. Dengan demikianpembelajaran keaksaraan sekaligus menjadi stimulus bagi tumbuhnya kesadaran akannilai-nilai moral sebagaimana yang terkandung dalam materi bacaan anak.

Selain itu, pengembangan kegiatan keaksaraan difokuskan pada keterlibatan anak secara aktif dalam berbagai kegiatan yang disediakan. Hal ini sesuai dengan pendapat yang menyatakan bahwa ketika anak diberi peluang dan disediakan sarana untuk seni, simbol-simbol tulis dan angkaangka, permainan drama, nyanyian, puisi, tarian, artefak budaya, dan buku-buku dan ditunjukkan kepada anak sejak usia dini maka anak mulai mengembangkan bahasa dan keterampilan literasi yang akan berlangsung seumur hidupnya (McLachlan \& Arrow, 2014).

Kegiatan pembelajaran keaksaraan dengan melibatkan kegiatan pembacaan cerita dengan menggunakan buku bergambar umumnya sudah digunakan di TK. Kegiatan ini memungkinkan anak untuk mengembangkan ide-ide dan mulai mengembangkan konsep-konsep melalui bahasa. Melalui cerita, anak belajar untuk mengekspresikan dan mengembangkan imajinasi mereka. Selain itu, pengembangan kecintaan membaca adalah penting pada masa transisi anak menuju jenjang sekolah selanjutnya di saat kemampuan membaca dan menulis semakin ditingkatkan (Tunmer et.al, 2008). Pengembangan literasi yang didukung dengan beragam sumber memungkinkan anak akan menjadi manusia yang literate (mahir wacana) dan memiliki karakter baik seiring dengan pengetahuan yang luas serta contoh-contoh budi pekerti baik yang diperoleh dari berbagai sumber.

\section{SIMPULAN}

Simpulan hasil penelitian pengembangan kegiatan keaksaraan berbasis pendidikan karakter di TK sebagai berikut. Pertama, kemampuan keaksaraan anak TK pada umumnya telah mencapai perkembangan normal dalam tahap kemunculan literasi, meliputi kemampuan dengar-bicara dan baca-tulis. Kendala dan kebutuhan guru dalam pengembangan keaksaraan, diantaranya kurangnya peralatan dan materi, buku sumber, sarana dan fasilitas yang memadai, lingkungan sekolah yang kurang mendukung. Berdasarkan data perkembangan dan kebutuhan guru disusun buku pedoman guru berisi tentang konsep-konsep keaksaraan di TK, pendidikan karakter di TK, serta model-model 
kegiatan pengembangan keaksaraan berbasis pendidikan karakter. Desain pengembangan kegiatan keaksaraan difokuskan pada kegiatan menstimulasi kemunculan kemampuan dengar-bicara dan baca-tulis sesuai dengan tahap perkembangan anak TK serta dengan memasukkan pendidikan karakter dalam setiap komponen pembelajaran.

Dari simpulan hasil penelitian dapat direkomendasikan kepada guru dan para pendidik PAUD: (1) melakukan observasi dan evaluasi terhadap perkembangan anak khususnya terkait dengan kemunculan literasi untuk digunakan sebagai dasar perencanaan dalam mengembangkan literasi, (2) melibatkan anak secara aktif dalam praktik keaksaraan dan berbasis karakter dengan cara memasukkan unsur-unsur pendidikan karakter pada semua komponen perencanaan pembelajaran keaksaraan, baik pada komponen tujuan, materi, maupun langkah-langkah kegiatan, (3) menggunakan buku panduan yang telah tersusun untuk melaksanakana pembelajaran keaksaraan di TK.

\section{REFERENSI}

Borg, W. R. \& Gall, M. D. (1983). Educational research, an introdution. London: Longman, Inc Burns, P. C, Roe, B. D, Ross, E. P. (1996). Teaching Reading in Today's Elementary Schools. Boston: Houghton Mifflin Company.

Candrawati. (2015). Pendidikan anak usia dini dalam pendidikan Islam dan budaya. Makalah Disajikan dalam International Conference of All Care for Children on Early Childhood Development. 12-13 Juni 2015.

Cooper, J.D.; Kathrin H. Au. (2000). Literacy: Helping children construct meaning. Boston, New York: Houghton Mifflin Company.

Ellis, A., Pennau, J., Standal, T., Rummel, M.K. (1989). Elementary language arts instruction. New Jersey: Prentice Hall.

Implementasi. Jurnal Pendidikan, Volume 10 Nomor 2 September 2009 Hal 85-94. Jakarta: Universitas Terbuka.

Kementerian Pendidikan Nasional. (2010). Kurikulum taman kanak-kanak, pedoman pengembangan program pembelajaran di taman kanak-kanak. Jakarta: Dirjen Manajememn Pendidikan Dasar dan Menengah Direktorat Pembinaan TK dan SD.

Kementerian Pendidikan Nasional. (2010). Tingkat pencapaian perkembangan anak taman kanakkanak. Jakarta: Dirjen Manajememn Pendidikan Dasar dan Menengah Direktorat Pembinaan TK dan SD.

Kemeterian Pendidikan dan Kebudayaan. (2015). Pedoman pengenalan kurikulum pendidikan anak usia dini. Jakarta: Direktorat Jenderal Pendidikan Anak Usia Dini dan Pendidikan Masyarakat.

Lickona, Thomas. (2013). Educating for character. Terjemah: Lita S. Pendidikan karakter: Panduan lengkap mendidik siswa menjadi pintar dan baik. Bandung: Penerbit Nusa Media.

McLachlan, C., \& Arrow, A. (2014). Promoting alphabet knowledge and phonological awareness in low socioeconomic child care settings: A quasi experimental study in five New Zealand centers. Reading and writing, vol. 27(5), 819-839. Retrieved from Proquest Database: doi:http://dx.doi.org/10.1007/s11145-013-9467-y.

Megawangi, R. (2009). Menyemai benih karakter. Jakarta: Indonesia Heritage Foundation.

Spodek, B., Saracho, O. N. (1994). Right from the start, teaching children ages three to eight. Massachusetts: Allyn and Bacon. 
Sugiyono. (2009). Metode penelitian kuantitatif kualitatif dan $R \& D$. Bandung: Penerbit Alfabeta. Tunmer, W. E., Nicholson, T., Greaney, K. T., Prochnow, J. E., Chapman, J. W., \& Arrow, A. W. (2008). PIRLS before swine: A critique of New Zealand's national literacy strategy. New zealand journal of educational studies, vol. 43(2), 105-119. Retrieved from http://search.proquest.com/docview/220903813?accountid=15035.

Wardani, I.G.A.K. (2009). pendidikan karakter, kajian konseptual dan kemungkinan. 